\title{
Leadership Practices and Strategies to resolve teachers' challenges in Cameroon Secondary Schools
}

\author{
Awu Isaac Oben ${ }^{\mathrm{a}}$ \\ a isaacoben87@gmail.com Tel: +8618696549905 \\ ${ }^{a}$ Faculty of Education, Southwest University, Chongqing, China
}

\begin{abstract}
The absence of sufficient and effective support from school principals towards teachers' challenges leaves most teachers to suffer a deficiency in their teaching-learning process, which of course makes it difficult to influence teaching quality and school improvement in general. From this background, this study aimed at increasing the understanding of leadership practices and strategies suitable for resolving teachers' challenges in Cameroon Secondary Schools. Based on this systematic literature review, among many, this study reveals that there is a solid significant relationship between leadership practices and resolution of teachers' challenges in secondary schools, at the same time, both the school principals and teachers need professional growth, at varying degree. The school principals need to be more skillful, experienced, and knowledgeable above an average teacher to be able to handle and resolve the challenges faced by teachers. Etc. In addition to the already existing effective practices and strategies from empirical evidence, such as; communication, conflict management, supervisory, motivation, boasting teachers' morale, promotion of teachers, promotion of good work environment, and cordial interpersonal relationships which positively influenced teachers' output/productivity Cameroon Secondary Schools, other more interactive practices and strategies such as; counseling, coaching, and mentoring, were found effective, yet neglected due to busy schedule of principals, so were encouraged to be used more frequently. Next, Shared Leadership, distributed leadership, transformational and instructional leadership practice are found to be effective in resolving teachers' challenges, as such should be used to empower and influence more teachers' experiences and development. Most importantly, instructional leadership practice appears more effective with respect to the challenges teachers face, hence should be the core of school principals' day-to-day administrative strategy because its effects such as quality feedback after supervision of instruction will solve most of the problems teachers encounter in schools. In addition, the ten (10) professional standards proposed by the National Policy Board for Educational Administration, which captures the principles of almost all the above leadership practices and strategies are encouraged to use as a guide for principals day to day running of schools. Because no one leadership practice and strategy is the best and comprehensive to tackle many teachers' challenges, this study resolves that school principals in Cameroon should make use of a combination of practices and strategies which can tackle teachers' challenges highlighted in this study. Finally, some strong recommendations were made.
\end{abstract}

Keywords: Leadership Practices and Strategies; teachers challenges; instructional leadership; transformational leadership; Secondary Schools in Cameroon; school improvement.

\section{Introduction}

Cameroon society and school context to be specific is rapidly changing and gradually becoming more complex with challenging roles especially in an environment that embraces and promotes modernization, and globalization. Such current trend and establishments has challenged students, teachers, schools and the 
entire educational system to rethink their structures, practices, strategies, and the competencies necessary for school leaders to improve their schools. Hargreaves, (2000) observed that "pressures and demands in some countries for students to learn new skills such as teamwork, higher-order thinking and effective use of new information technologies, call for new styles of teaching to produce these skills, meaning that more and more teachers are now having to teach in ways they were not themselves taught" The pressure of school improvement at micro-level falls directly on the shoulders of school leaders (principals), bearing in mind that Leadership is a process whereby an individual influence a group of individuals to achieve a common goal (Northouse, 2012) and poor performance of school leader is detrimental to school effectiveness and growth. As a consequence of this view, the expectations for school leaders have significantly changed and leaders are being held accountable for poor resource management and student academic performance (Busch, O'Brien \& Spangler, 2005). Based on this background this paper has a limited scope to do a systematic literature review describing the Leadership practices and strategies that can resolve teachers' challenges in Cameroon Secondary Schools.

\subsection{Research Context}

Like in any other country, Secondary education in Cameroon absorbs graduates from primary education, and prepares them for access into higher educational institutions. Such uniqueness, permits secondary education to occupy an indispensable central position and leading role in the education ladder (Etomes, and Molua, 2018). At the same time, Teaching is getting more and more complex and challenging these days. There by putting the teachers in a very difficult position to deal with new challenges like: large class size and inclusive education, lack of content knowledge in new disciplines like ICTs and STEM integration, etc. While teachers' challenges are on the rise, students' performances drop. Poor performance in secondary education which is reflected in students' output, such as; repetition, low skills acquired, dropout amongst others have adverse effects on the student in particular and the Cameroon society in general. For example, that school dropout at this level limit future opportunities for students and also represents a significant drain of the limited resources that countries have for the provision of secondary education (Etomes, and Molua, 2018).

Most of such problems that surface in the Cameroon school context always point accusation fingers to the school management and administration (school leadership). While most parents blame the entire school system, the administrators pressurize and blame teacher and the teachers in turn blame the students and school principals. Contrarily research has proven that the correlation between school leadership and students' outcomes is not direct. While the school leadership affects students' learning achievement by exercising a positive influence on the work of other staff, especially teachers, as well as on the conditions 
or characteristics of the school (Leithwood et al., 2006). Therefore the efficient and effective management of any school lies on the ability of the top leadership to motivate the workforce. And because most research points out that, teachers play a pivotal role in the achievement of educational goals and objectives given that their effectiveness determines students output. This is also backed by Section 37(1) of Law No. 98/004 of 14th April 1998 to lay down the guidelines of education in Cameroon which states that; "the teacher shall be the principal guarantor of quality education". Though there are other factors that contribute to teachers' productivity, principals as head of secondary schools has a paramount role to play in teachers' job performance (Etomes, and Molua, 2018).

Generally Cameroon secondary schools officially headed by school principals and directly by assisted vice-principals while other administrative positions like discipline master, school cashers, sectary etc complement the school leadership. The Principals is an administrative head or chief executive of the institution who plan, control and command, organize and coordinate all the activities that take place in the school (Mbua, 2003 cited in Ngwokabuenui 2015). It is important to mention that, School leaders start out as teachers and advance to the position of school leader at the end of their teaching career. Wirba (2015) attest that "the speed at which classroom teachers are turned into school principals indicate the lack of emphasis on leadership training for current principals in schools in Cameroon, meaning the average school principal in Cameroon context has no special qualities and experiences over the teaching staff. This seniority-based transition of teacher to school leadership (recruitment policies and procedures) therefor overlook knowledge and experience of education management and leadership with the assumptions that the new principals has already got relevant experiences for his new role and will have more skills and experiences on the job training. And since, the principal is the head of the school and the manner in which the principal performs his/her roles and functions are paramount in improving the teaching and learning environment for teachers to be productive. Principals are the main administrators of staff and students who are at the center of school improvement; teachers are at the center of the teaching-learning process while students are the major stakeholders in education since their performance informs the educational community on how the school is faring (Etomes, and Molua, 2018).

\subsubsection{Teachers and Teaching Challenges in Cameroon Secondary Schools}

The pressure to raise the average student standard and performances put the school administrator and teacher most specifically in very difficult position. Many classroom teachers in Cameroon secondary schools face a lot of challenges and such challenges decreases the quality of the teachers. Backed by previous research conducted by (Alemnge, 2015, Ngwokabuenui 2015, Kongnyuy, 2015, Etomes, and Molua, 2018, Wiysahnyuy, 2019, Oben, 2020) and for the purposed of this study, I have captured and 
summarized the top six (6) main problems which are affecting secondary school teachers on daily biases, and such problems are affecting teachers, teaching quality, students' performances and school development in general. They include;

1) Heavy work load due to shortage resources (both financial and human) which limits most teachers to have time in planning lessons properly and extra time for self and professional development and engagement in research. Usually in schools with limited number of teachers, the workload for an individual teacher becomes even higher. For example, in a school where there is only a mathematics teacher, without a physic teacher, he or she may be asked to teach both subjects, with the assumption that he has related subject matter knowledge of the two subjects. But this is not always true, since each teacher had some level specialization while a student teacher.

2) The issue of Classroom management due to large class size and of diversity and inclusive education. Teaching an average classroom poses a lot of challenges to teachers, especially to inexperienced teachers. More students in classroom require more work, more resources and so on. For example teaching student in sciences where they may need some practical work, teachers usually face a lot of problem due to lack of resources (classroom space and funds for projects) and the issue of attending to different students need (diversity and inclusiveness) in the same class possess even bigger challenges.

3) Poor feedback from school leaders, such as supervision of instruction. This occurs when principal has limited knowledge of the subject matter. Most research report that when principal background knowledge for example is not sciences, after observing a classroom, they usually do no give concrete subject matter feedback which can effectively guide the teacher, rather, they give more of pedagogical feedback, which has also incomplete because of their poor knowledge in subject matter being observed. In some cases, even when, the principal and there teacher have, same educational background, the teacher maybe be more experienced than then principal, so the principal has little or nothing to offer as feedback which can improve the teaching learning process.

4) Poor working conditions which leads to low job satisfaction (low salaries, little or no evolvement in relevant school decision making, recognition, etc). This situation affects teachers' motivation, commitment and effective collaboration with peers or other staff members. The situation sometime ironical leads to rampant teachers' lateness and absenteeism in class, which leave the teaching learning process in a dilemma. Absenteeism of teachers is one of the main reasons generally considered to contribute to the poor level of education in the Cameroon. 
5) Lack of proper pedagogical skills and content knowledge delivery to effective Integrate 21st century learning skills like ICTs and STEM in the classroom. This situation frequently happen because some teacher do not possess proper professional training given that the school curriculum keeps changing, hence it come with new expectations and challenges. An example of reason accounting for teacher lack of pedagogical and subject matter knowledge is the school autonomy policy which allows school administrator together with Parent teachers association to recruit teachers. On the contrary, because the demand for qualified teachers is a major problem in some Cameroon secondary schools, the high demand for teachers (quantity) seems more urgent than questions of quality. Usually, because of shortage (financial and human resources), the school takes the calculated risk to fill this gap with the provision of PTA, contract or volunteers teachers (school-based teacher recruitment autonomy policy) as the problem of shortage is almost unavoidable while at the same time neglecting issues of teachers quality and education standards. Mostly, it's up to schools' parent-teacher associations to fill the gaps with the so-called "PTAteachers" or some undeserving mediocre teachers who are employed based on, but no limited; favoritism, nepotism, discrimination, bribery and corruption, and in most cases have no formal teachers training. Sad enough, most PTA teachers lack or have insufficient professional training or preparations, required certification, poor professional ethics, and little pedagogic experience to be considered qualified teachers. These poor situations which provide the school with mediocre or less qualified teachers usually have a general assumption that the new employee will learn pedagogical skills on the job via in-service training and assistance from the school principal. However, due to limited career prospects and inadequate motivational support and rewards, these teachers are usually reluctant towards self-development and are less committed to their job and fail to seek professional development. The school principals are then held accountable and the burden usually falls on their shoulders and challenged with a huge task or role to bridge the gap of inexperienced or unqualified teachers found in their schools in order to increase average student performance (Oben, 2019). From this perspective, it means the average school principal in Cameroon need to work even hard to improve teacher quality, because such problem of recruiting inexperienced and untrained teachers is almost unavoidable especially in the typical rural areas of the country.

6) Students' indiscipline in secondary schools in Cameroon has recently increased, thereby putting the teaching learning process more difficult for teachers. Ngwokabuenui (2015) observed that, students have become uncontrollable and highly disrespectful to: themselves, teachers, school administrators, parents and to the society at large. Students portray different types of indiscipline behavior among which include the following acts: boycotting of lessons, watching and practicing pornography, lies telling, 
violence, dishonesty, disobedient to teachers, prefects, and school administration, rapping school/class mates, alcohol consumption, confronting and stabbing teachers in schools, vandalism, lateness to school, cultism, drug abuse, insulting/assaulting, stealing, rioting; among others. The presence of the above mention problems usually water down the efforts of most teachers as they struggle to improve students' performances. For this reason, the researcher proposed some possible remedies to curb indiscipline in secondary schools. They include; moral leadership, moral education/instruction, education orientation and behavior-accountability policy implementation. It is therefore imperative to note here that, the responsibilities and contribution of school principals through strategic leadership practices are the only immediate solution to assist Cameroonian teachers in overcoming the aforementioned challenges.

\subsection{Statement of the Problem}

The correlation between school leadership and students' outcomes is not direct. Research indicates that school leadership affects students' learning achievement by exercising a positive influence on the work of other staff, especially teachers, as well as on the conditions or characteristics of the school (Leithwood et al., 2006). At the same time many classroom teachers in Cameroon secondary schools faces a lot of challenges like insufficient pedagogical and content knowledge, poor working conditions and poor feedback from supervision of instruction etc, which generally affect their motivation, commitment and job satisfaction, thereby affecting teaching quality, students' performance and the entire school development, because without teachers, the education system will be crippled and no educational system can rise above the quality of its teachers (Endeley, 2014, Etomes \& Molua, 2015,). The aforementioned problems of teachers can be addressed by some effective leadership practices and strategies. However, many researches which coincide with the actual situation in Cameroon context indicates that few principals actually engage in practices and strategies which resolve teachers challenges in their day-to-day work, spending minimal time on instructional leadership activities, coaching, and teacher evaluation and support (Horng, Klasik, \& Loeb, 2009; May, Huff, \& Goldring, 2012; Grissom et al., 2013). Rather, principals tend to spend the bulk of their time on administrative activities (e.g., student discipline and compliance requirements), budgets and staff, and internal and external relations, such as fundraising and working with staff and students (Horng et al., 2009).

The absence of sufficient and effective support from school principal towards teachers challenges leave most teachers to suffer a deficiency in their teaching learning process which makes it difficult to influence school improvement in general. Based on this background, this paper is a systematic literature review describing the practices and strategies which principals can use to resolve teachers challenges in Cameroon Secondary Schools, and to suggest how trainings could improve performance of current and future principals and teachers. 


\subsection{Purpose of the Study}

The purpose of this study is to increase understanding on the leadership practices and strategies suitable for resolving teachers' challenges in Cameroon Secondary Schools, thereby reducing some problems encountered by teachers within the Cameroon context.

\subsection{Research Questions}

This paper set out to answer the following question:

1. What are some suitable leadership practices and strategies school principals can use to resolve teachers challenges in Cameroon Secondary?

\subsection{Significant of the Study}

It is predicted that, this study will be a suitable attempt and mechanism to understand, describe and suggest possible solutions to tackle problems affecting teachers' development in Cameroon secondary schools. It is hoped that discussion and suggestion from this paper will be significant and beneficial to the following groups of persons; school administrators / policy makers, teachers, students, the media, and the society at large.

\section{Review of Related Literature}

Leadership practices are uniquely defined by the actions that leaders perceive as necessary to 'respond to specific student, teacher and community needs' (Urick and Bowers 2014, 99 cited in Walker \& Qian, 2020). By executing such practices, school principals (leaders) are capable of having significant positive effects on student learning and other important outcomes (Robinson, Hohepa, \& Lloyd, 2009; Silins \& Mulford, 2002; Waters, Marzano, \& McNulty, 2003, Cited in Leithwood, et.al., 2010). Based on an extensive literature review and relevant empirical evidence, Leithwood et al. (2008) found that 'almost all successful (school) leaders draw on the same repertoire of basic leadership practices'. These are: (i) building vision and setting directions; (ii) understanding and developing people; (iii) redesigning the organization; and (iv) managing the teaching and learning programme. Each of these basic practices is associated with numerous, more specific competencies, orientations and considerations (Leithwood et al., 2004). While the authors identify these practices as necessary for leaders who wish to improve student learning in their schools, they also acknowledge that they are, by themselves, rarely sufficient. Other policies and strategies must be in place to ensure the effectiveness of good leadership practice. Evidence from the literature suggests that leaders use this common repertoire of basic leadership practices in diverse ways, adopting different styles or models to achieve organizational goals or to meet targets. And Effective leaders vary their methods according to the context, the stakeholders affected and the desired outcome. 
Research suggests that a core set of principal leadership practices, from human capital management to agenda setting to coaching and instructional leadership, can influence teaching and learning in schools (Hallinger \& Heck, 1998; Leithwood, Louis, Anderson, \& Wahlstrom, 2004; Harris, Rutledge, Ingle, \& Thompson, 2010 cited in Rowland 2017). Given that most of the teachers problems highlighted above are relate to instructional leadership and transformational leadership practice, it is significant to discuss the concept of instructional leadership and transformational leadership because it is very instrumental in teachers' development, hence the improvement of teaching quality.

\subsection{Instructional Leadership Practice}

Different authors have different conceptualization about the concept of instructional leadership. some the examples are the views that; Instructional leadership focuses predominantly on the role of the school principal in coordinating, controlling, supervising, and developing curriculum and instruction in the school (Bamburg \& Andrews, 1990; Hallinger \& Murphy, 1985), Instructional leaders lead from a combination of expertise and charisma. They are hands-on principals, 'hip-deep' in curriculum and instruction, and unafraid of working with teachers on the improvement of teaching and learning (Cuban, 1984; Hallinger \& Murphy, 1986). Instructional leaders are viewed as culture builders. They sought to create an 'academic press' that fosters high expectations and standards for students, as well as for teachers (Mortimore, 1993; Purkey \& Smith, 1984).

According to (Hallinger, 2003) the most frequently used conceptualization of instructional leadership was developed by Hallinger (2000). In this model he proposes three dimensions of the instructional leadership construct which are: (1) Defining the school's mission, (Two functions, framing the school's goals and communicating the school's goals, comprise the dimension, defining the school's mission) These functions concern the principal's role in working with staff to ensure that the school has clear, measurable goals that are focused on the academic progress of its students. It is the principal's responsibility to ensure that these goals are widely known and supported throughout the school community. While this dimension does not assume that the principal defines the school's mission alone, it does assume that the principal's responsibility is to ensure that the school has a clear academic mission and to communicate it to staff. (2) Managing the instructional program, (focuses on the coordination and control of instruction and curriculum) this dimension incorporates three leadership functions: supervising and evaluating instruction, coordinating the curriculum, monitoring student progress. These functions, more so than functions in the other two dimensions, require the leader to be deeply engaged in the school's instructional development. In larger schools, it is clear that the principal cannot be the only person involved in leading the school's instructional program. Yet this framework assumes that development of the academic core of the school is 
a key leadership responsibility of the principal (Hallinger \& Murphy, 1985). And (3) Promoting a positive school-learning climate (includes several functions: protecting instructional time, promoting professional development, maintaining high visibility, providing incentives for teachers, providing incentives for learning) This dimension is broader in scope and intent. It conforms to the notion that effective schools create an 'academic press' through the development of high standards and expectations and a culture of continuous improvement. It is the responsibility of the instructional leadership to align the school's standards and practices with its mission and to create a climate that supports teaching and learning. (Hallinger, 2003). Looking at these definitions, they all captures main practices and strategies used by principals with respect to teachers' development hence resolving most of the challenges which which teachers face.

\subsubsection{Transformational Leadership}

Very close to the concept of instructional leadership is transformational leadership. Hallinger (2003) reported that the most suitable leadership role for principals has been dominated by two conceptual models: instructional leadership and transformational leadership. According to UNESCO (2016) this theory contends that: (i) people will follow a person who inspires them; (ii) a person with vision and passion can achieve great things; and (iii) the way to get things done is by injecting enthusiasm and energy. Thus, transformational leaders create and embrace a vision for an organization that inspires and brings the best out of people, while reflecting a belief system based on integrity and inclusiveness. This evolution of the educational leadership role has been labelled as reflecting 'second order' changes (Leithwood, 1994 cited in Hallinger 2003) as it is aimed primarily at changing the organization's normative structure. The most frequently used model of this variety has been transformational leadership (e.g. Bass, 1985, 1997; Leithwood \& Jantzi, 2000b; Silins \& Mulford, 2002 cited in Hallinger, 2003 ). Transformational leadership focuses on developing the organization's capacity to innovate. Rather than focusing specifically on direct coordination, control, and supervision of curriculum and instruction, transformational leadership seeks to build the organization's capacity to select its purposes and to support the development of changes to practices of teaching and learning. Transformational leadership may be viewed as distributed in that it focuses on developing a shared vision and shared commitment to school change (Hallinger 2003).

Furthermore, based on the existing literature, most of the above practices and strategies have be summaries and documented in "Professional Standards for Educational Leaders" proposed by National Policy Board for Educational Administration (2015) as presented in the table below. 
Table 1. Professional Standards for Educational Leaders (NPBEA, 2015)

\begin{tabular}{|c|c|c|}
\hline Professional Standards & & Mission Statement \\
\hline $\begin{array}{l}\text { 1. Mission, Vision, and } \\
\text { Core Values }\end{array}$ & $\checkmark$ & $\begin{array}{l}\text { Effective educational leaders develop, advocate, and enact a shared mission, vision, and core } \\
\text { values of high-quality education and academic success and well-being of each student. }\end{array}$ \\
\hline $\begin{array}{l}\text { 2.Ethics and Professional } \\
\text { Norms }\end{array}$ & $\checkmark$ & $\begin{array}{l}\text { Effective educational leaders act ethically and according to professional norms to promote } \\
\text { each student's academic success and well-being. }\end{array}$ \\
\hline $\begin{array}{l}\text { 3. Equity and Cultural } \\
\text { Responsiveness }\end{array}$ & $\checkmark$ & $\begin{array}{l}\text { Effective educational leaders strive for equity of educational opportunity and culturally } \\
\text { responsive practices to promote each student's academic success and well-being. }\end{array}$ \\
\hline $\begin{array}{l}\text { 4.Curriculum, } \\
\text { Instruction, and } \\
\text { Assessment }\end{array}$ & $\checkmark$ & $\begin{array}{l}\text { Effective educational leaders develop and support intellectually rigorous and coherent } \\
\text { systems of curriculum, instruction, and assessment to promote each student's academic } \\
\text { success and well-being. }\end{array}$ \\
\hline $\begin{array}{l}\text { 5. Community of Care } \\
\text { and Support For Students }\end{array}$ & $\checkmark$ & $\begin{array}{l}\text { Effective educational leaders cultivate an inclusive, caring, and supportive school community } \\
\text { that promotes the academic success and well-being of each student. }\end{array}$ \\
\hline $\begin{array}{l}\text { 6. Professional Capacity } \\
\text { of School Personnel }\end{array}$ & $\checkmark$ & $\begin{array}{l}\text { Effective educational leaders develop the professional capacity and practice of school } \\
\text { personnel to promote each student's academic success and well-being. }\end{array}$ \\
\hline $\begin{array}{l}7 . \quad \text { Professional } \\
\text { Community for Teachers } \\
\text { and Staff }\end{array}$ & $\checkmark$ & $\begin{array}{l}\text { Effective educational leaders foster a professional community of teachers and other } \\
\text { professional staff to promote each student's academic success and well-being. }\end{array}$ \\
\hline $\begin{array}{l}8 . \\
\text { Engagement of Families } \\
\text { and Community }\end{array}$ & $\checkmark$ & $\begin{array}{l}\text { Effective educational leaders engage families and the community in meaningful, reciprocal, } \\
\text { and mutually beneficial ways to promote each student's academic success and well-being. }\end{array}$ \\
\hline $\begin{array}{l}\text { 9. Operations and } \\
\text { Management }\end{array}$ & $\checkmark$ & $\begin{array}{l}\text { Effective educational leaders manage school operations and resources to promote each } \\
\text { student's academic success and well-being. }\end{array}$ \\
\hline 10. School Improvement & $\checkmark$ & $\begin{array}{l}\text { Effective educational leaders act as agents of continuous improvement to promote each } \\
\text { student's academic success and well-being. }\end{array}$ \\
\hline
\end{tabular}

In October 2015, the National Policy Board for Educational Administration (NPBEA) released new standards for school leaders the PSEL. Compared with previous standards (the Interstate School Leaders Licensure Consortium (ISLLC) The new standards put more emphasis on principals' responsibilities to promote rigorous instruction, build individual teacher and leader capacity, foster a collaborative work environment, ensure the development of equitable and culturally responsive schools, and engage families and communities (Rowland, 2015b; Prociw \& Eberle, 2016). Specifically Standard 6: (Professional Capacity of School Personnel) and Standard 7: (Professional Community for Teachers and Staff) of the new standards suggest that principals should focus on empowering teachers, and cultivating and integrating the school with the community. Thereby resolving most of the challenges faced by teachers, hence improving teaching quality and school improvement. 


\subsection{Empirical Review}

To begin with, Wiysahnyuy (2019) examined some factors that contribute to ineffective teaching in some selected secondary schools in Bamenda municipality in the North West region of Cameroon. Findings from this study revealed that majority of the teachers hardly carried out intensive research and that hindered effective mastering of the content knowledge of the lessons taught. Some of them used methods that were more of teacher-centered, majority of the teachers scarcely prepared their lessons before the actual teaching and some did not consider the differences in learners learning styles during the teaching-learning transaction. Verbal communication in the classroom was more of teacher-centered. Most of the teachers used basically traditional materials neglecting the use of advanced media and community resources while only $30 \%$ of the teachers made an effort to create awareness on the purpose and importance of the knowledge learners learned. All these rendered the teaching-learning transaction less effective. In order to improve on this situation, the researcher suggested that teachers should carry out intensive research, effectively prepare their lessons, vary and use the constructivist approaches of teaching so as to meet up with the demands of Competence-Based Learning and complement the use of traditional media with advanced and community resources.

Next, a study by Kongnyuy, (2015) which aimed at identifying and examining the effects of motivation on teacher output in Government Secondary and High Schools in the North West Region of Cameroon, revealed that; boasting teachers' morale, promotion of teachers, good work environment and cordial interpersonal relationships positively influenced teachers' output. The researcher of this study recommended that principals should strengthened in-service training facilities for teachers; appointment into posts of responsibilities should consider qualification, experience and personal skills of the teacher concerned; and that trust, confidence, delegation of power and shared decision making should be encouraged amongst principals.

Last but not the least, a study by Etomes and Molua, (2019) investigated strategies used by principals for enhancing the productivity of secondary school teachers in selected government secondary schools in Cameroon. Results from this study showed that, principals' communication, conflict management, supervisory and motivation strategies influence the productivity of teachers in Government Secondary Schools. Of the four strategies examined, conflict management strategy was found to have more influence on the productivity of teachers. Principals' strategies have a direct relationship with teachers' productivity. Therefore, there is a possible correlation between principals' leadership and management strategies, teachers' productivity and school effectiveness. In addition, effective collaboration amongst teachers is necessary for teachers' effectiveness. The researchers recommended that principals should put in strategies 
that will enhance effective communication, conflict management, motivation and supervision to improve on the productivity of teachers.

\section{Discussion}

There exist a plethora of challenges affecting teachers in Cameroon secondary schools. The prominent ones include; (1) Heavy work load due to shortage of resources (human, financial, and material) in schools. (2) Classroom management issue due to large class size, diversity and inclusive education. (3) Poor feedback from school leaders. (4) Poor working conditions which leads to low job satisfaction (5) Lack of proper pedagogical skills and content knowledge due to insufficient professional training or preparations.

(6) Recent increase students' indiscipline in secondary schools in Cameroon.

This study reveals that, there is a solid significant relationship between leadership practices and resolution of teachers' challenges in secondary schools, at the same time, both the school principals and teachers needs professional growth, at varying degree. The school principals needs to be more skillful, experienced and knowledgeable above an average teacher so as to be able to handle and resolve the challenges faced by teachers in schools. This coincide with findings of Etomes and Molua, (2019) which showed that, principals' communication, conflict management, supervisory and motivation strategies influence the productivity of teachers in Government Secondary Schools, and effective collaboration amongst teachers is necessary for teachers' effectiveness. In addition, a study by Kongnyuy, (2015) found that; boasting teachers' morale, promotion of teachers, good work environment and cordial interpersonal relationships (motivation) positively influenced teachers' output. Therefore, there are different practices and strategies school principals can use depending on the context, time, situation and most importantly the ability of the school principal to influence such actions. Therefore the utilization of the ten (10) professional standards proposed by National Policy Board for Educational Administration (2015) which captures most of the leadership practices, and are closely related to the result of Leithwood et al. (2008) will be applicable by school principals in Cameroon context, towards teachers, teaching quality and school improvement. In addition I therefore agree with the authors who suggest that Principals' strategies have a direct relationship with teachers' productivity and to suggest just as Leithwood et al., (2004), that principals in Cameroon should use more interactive strategies such as counseling, coaching, teacher evaluation and support, and mentoring to resolve teachers challenges. These interactive strategies can effectively influences teachers development, hence student and school improvement in Cameroon.

More, this study highlights that, the current practices and strategies employed by school principals in Cameron are not sufficient to tackle most of the contemporary challenges face is schools. This happen 
because of insufficient professional training or preparations into office, for such related reasons, few principals actually engage in practices such as coaching, instructional leadership, and transformational leadership that can influence teaching and learning in schools in their day-to-day work, spending minimal time on instructional leadership activities, coaching, and teacher evaluation and support (Horng, Klasik, \& Loeb, 2009; May, Huff, \& Goldring, 2012; Grissom et al., 2013 cited in Rowland, 2017). Rather, principals tend to spend the bulk of their time on administrative activities (e.g., student discipline and compliance requirements), budgets and staff, and internal and external relations, such as fundraising and working with staff and students (Horng et al., 2009). These challenges remain part of the school principals' responsibility to revolve and to increase teachers' motivation in the teaching-learning processes. Kongnyuy, (2015) remarked that, satisfied teachers are generally productive and can influence students' achievement. Therefor improvement in the working conditions of teacher through leadership practices and strategies like teachers recognition and involvement in major decision making process will greatly influence teachers jobs satisfaction, hence productivity.

Furthermore, this study reveal that most teachers, especially the novice and inexperienced depend on their principal for their professional growth, and since teacher's administrative expediencies and seniority count in their transition to become school principals in future, the school principal need to use more strategies and practices that can lead to equity and teachers growth, if this problem is not resolved many school leaders in Cameroon secondary schools will continue to be unprepared for their new roles and responsibilities since the selection of principals is often on the basis of teacher seniority. This coincide with finding of ( Etomes \& Molua, 2018) who found that, a very large proportion of the teachers in secondary schools in Cameroon (96.6\%) do not hold any post of responsibility while $3.4 \%$ teachers hold post of responsibility. This points therefore point back to some of the teachers' problems like lack of support and recognition, which may lead to less commitment in the job and absenteeism. In this case, school principals should use shared Leadership and distributed leadership to influence more teachers' experiences and development, because it is certain that in future, most of the current school teachers will become principal, following longevity, and experience in the Cameroon context. Shared leadership reflects the culture of working in unity presented by shared leadership behaviors by all stakeholders (Bakir, 2013 cited in Goksoy, 2016). Therefore, the shared leadership approach is related to the participation of many individuals in leadership activities. It is more than one leader's knowledge and experiences; it is rather the product of many individuals and the relationships among them by combining all the leaders in a school and taking their activities into account (Harris, 2005; Spillane, 2005). Similarly, school principals should use distributed leadership practices to complement their practices and strategies. This is because distributed leadership is not simply assigning individuals to specific tasks and sharing duties (Penlington et al., 2008 
cited in Goksoy, 2016). Rather, this type of leadership, is collective work as well as collective learning by working on goals through communication and interaction is prominent, rather than individual work (Halverson, 2007). For instance, capacity building of one teacher by another teacher is an example of this process (Copeland, 2003). It has a much larger effect than the sum of all leaders in a school and their efforts to reach a larger scale leadership behavior (Spillane, 2006).

Last but not the least, the study also revealed the effective use of instructional and transformational leadership practice can actually resolve most of the challenges teacher face in school. Multiple researches points out that instructional leadership are 'the longest established concept linking leadership and learning' (Bush, 2013). Leithwood and Seashore-Louis (2011) argue that knowledge and understanding of classroom practice play a significant role in instructional leadership, allowing principals to provide teachers with detailed and quality feedback and make suggestions for change. Although school leaders have little direct influence on student achievement, 'they can indirectly influence students' progress by supporting those in the school who work most directly with the students: classroom teachers' (Hallam, et al., 2013, p. 510). Louis, Leithwood, Wahlstrom, and Anderson (2010) argue that leadership is second only to classroom instruction as an influence on student learning. On the other hand, transformation leadership is another powerful leadership practice which the school principal can engage in to improve teachers' quality and solve most of the teacher because transformational leaders create and embrace a vision for an organization that inspires and brings the best out of people, while reflecting a belief system based on integrity and inclusiveness. (UNESCO 2016). Previous research from Cameroon, greatly signal the need for effective use of instructional and transformational leadership practice in Cameroon secondary schools. For example, Wiysahnyuy (2019) found that majority of the teachers hardly carried out intensive research and that hindered effective mastering of the content knowledge of the lessons taught. Some used teacher-centered methods, majority of the teachers scarcely prepared their lessons before the actual teaching and some did not consider the differences in learners learning styles during the teaching-learning transaction. Most teachers used traditional materials and neglecting the use of advanced media and community resources, etc all of which rendered the teaching-learning transaction less effective. Thefore that application for instructional and transformational leadership practice, can help to challenges such as lesson planning and classroom management through supervision of instruction, which of Couse can improve on teachers pedagogical skills and content knowledge, through concrete feedback received. The teachers through transformational professional growth can also learn from the principal on to students' indiscipline. To resolve the problem of heavy work load, the principal can at time, teach some classes in his or her area of competence. 


\subsection{Recommendations}

This study established that, the school principals need to be more skillful, experienced and knowledgeable above an average teacher so as to be able to handle and resolve the challenges faced by teachers in schools. Consequently this study proffers the following recommendations: They include;

1) Revising the qualifications requirements for the role of school leader is a pressing need in Cameroon context. Candidates for school leadership roles, principals to be specific need more than just a degree in education and some experience in management. Cameroon government need to prioritize and professionalize leadership in schools.

2) Policies determining the period of appointment for school leaders need to be put in place. Principals should be contracted to a school for a specific, fixed period of time, after which he or she moves to a leadership position at another school. This would reduce the chances of leaders using authoritarian approach, thereby encouraging them to share and distribute leadership. It would also help motivate and challenge experienced principals across their careers. This, in turn, helps professionalize school leadership. 3) Adequate preparation prior to appointment would help principals overcome the shock of transition and enable them to come to terms with their new role. Professional development should continue after appointment to support principals in tackling diverse challenges at school. This may include but not limited to; conferences, workshops, and taking some short leadership and pedagogic courses to improve their skills, knowledge and professional attitude.

4) Private secondary schools should also be monitored to ensure the quality for school leadership running across the country, because poor leadership practices will lead to adverse effects on the teachers, teaching quality, students' performances and school improvement in general.

5) Given that, no one leadership practice and strategy is the best and comprehensive to tackle many teachers' challenges, this study resolves that school principals in Cameroon should make use of a combination of practices and strategies which can tackle teachers' challenges highlighted in this study.

\section{Conclusion}

The school principal is the custodian of the school's vision, missions, and values. As a result, he/she should provide the inspiration to achieve the school's vision and missions, grow people to achieve the school's vision and missions, thrive on change to lead the school towards its chosen destination, and collaborate with different interest groups to achieve the school's vision and missions. In addition to the already existing effective practices and strategies $\mathrm{f} \mathrm{m}$ empirical evidence, such as; communication, conflict management, supervisory, motivation, boasting teachers' morale, promotion of teachers, promotion of good work environment, and cordial interpersonal relationships which positively influenced teachers' output/productivity Cameroon Secondary Schools, other more interactive practices and strategies such as; 
counseling, coaching, and mentoring, were effective, yet neglected due to busy schedule of principals, so were encouraged to be used more frequently. Next, Shared Leadership, distributed leadership, transformational and instructional leadership practice are found to be effective in resolving teachers' challenges, as such should be used to empower and influence more teachers' experiences and development. Most importantly, instructional leadership practice appears more effective with respect to the challenges teachers face, hence should be the core of school principals' day-to-day administrative strategy because its effects such as quality feedback after supervision of instruction will solve most of the problems teachers encounter in schools. In addition, the ten (10) professional standards proposed by the National Policy Board for Educational Administration, which captures the principles of almost all the above leadership practices and strategies are encouraged to use as a guide for principals day to day running of schools. Because no one leadership practice and strategy is the best and comprehensive to tackle many teachers' challenges, this study resolves that school principals in Cameroon should make use of a combination of practices and strategies which can tackle teachers' challenges highlighted in this study. Principals and teachers should also engage in some form of internal or external professional development such as conferences, workshops, and taking some short leadership and pedagogic courses to improve their skills, knowledge, and professional attitude.

\section{References}

Alemnge, F.L ( 2015) Distance Education at the University of Buea, Cameroon; Journal of Educational Policy and Entrepreneurial Research (JEPER) ISSN: 2408-770X (Print), ISSN: 2408-6231 (Online)Vol.2, N0.1,. Pp 34-42

Barnett, C. \& Tyson, P. (1999). Case methods and teacher change: Shifting authority to build autonomy. In M. Lundberg, B. Levin, \& H. Harrington (Eds.), Who learns what from cases and how?: The research base for teaching and learning with cases (pp. 53-69). Mahwah, NJ: Lawrence Erlbaum.

Bautista, A., \& Ortega-Ruíz, R. (2015). Teacher professional development: International perspectives and approaches. Psychology, Society and Education, 7(3), 240-251.

Brown C., Smith, M., \& Stein, M. (1996, April). Linking teacher support to enhanced classroom instruction.

CAMEROON, Ministry of Basic Education -MINEDUB (2018). Curriculum of Nursery and Primary School in Cameroon.

Chaubey, A.K., Tiwari, V \& Dubey, R. (2015) PROFESSIONALIZATION OF EDUCATION:A CRITICAL ANALYSIS : https://www.researchgate.net/publication/331543407 (accessed Mar 23 2020)

Col \& Retridal (2005) Workshop on Course Writing and Logistics for Distance Education, University of Buea, Cameroon

Col \& Retridal, (2006) Workshop on Course Writing for Open and Distance Learning, University of Buea, Cameroon

Day, C. (1999) Developing Teachers: the challenges of lifelong learning (London \& New York, Falmer Press).

Demirkasimogu, N. (2010). Defining "teacher professionalism" from different perspectives. Procedia-Social and Behavioral Sciences, 9, 2047-2051. World Conference on Learning, Teaching and Administration Papers. 
Ebot-Ashu, F ( 2015) Leadership and Management Development Programmes in Cameroon for primary school leaders : International Journal of Education and Social Science Vol. 2 No. www.ijessnet.com

Education Sector Division for Policies and Lifelong Learning Systems (ED/PLS) Section of Education Policy (ED/PLS/EDP)

Endeley, M. N. (2014). Teaching Practice in Cameroon: The Effectiveness of the University of Buea model and implications for quality.Australian Journal of Teacher Education, 39(11). http://dx.doi.org/10.14221/ajte.2014v39n11.9

Etomes, S. E \& Molua, E. L. (2018) Strategies for Enhancing the Productivity of Secondary School Teachers in South West Region of Cameroon; Journal of Education and Learning; Vol. 8, No. 1; 2019 ISSN 1927-5250 E-ISSN 1927-5269 Canadian Center of Science and Education. URL: https://doi.org/10.5539/jel.v8n1p109

Etomes, S. E \& Molua, E. L. (2018) Strategies for Enhancing the Productivity of Secondary School Teachers in South West Region of Cameroon; Journal of Education and Learning; Vol. 8, No. 1; 2019 ISSN 1927-5250 E-ISSN 1927-5269 Canadian Center of Science and Education. URL: https://doi.org/10.5539/jel.v8n1p109

Faculty of Education (2007) Providing Access to Quality Higher Education through Distance Education.

Farrell, T.S.C. (2008). Reflective Practice in the Professional Development of Teachers of Adult English Language

Gauna et al (1995) Social and educational change puts the teachers in a position in which they have to face situations and tasks for which they are not prepared and have not been socialized.

Gauna , P R D. Diaz, C. Gonzalez, V \& Garaizar I (1995) Teachers' Professional Development as a Process of Critical Action Research, Educational Action Research, 3:2, 183-194, DOI: 10.1080/0965079950030205

Goksoy, S. (2016). Analysis of the relationship between shared leadership and distributed leadership. Eurasian Journal of Educational Research, 65, 295-312 http://dx.doi.org/10.14689/ejer.2016.65.17

Gupta, A. (2006/2013). Early childhood education, postcolonial theory, teaching practices and policies in India: Balancing Vygotsky and the Veda. New York: Palgrave Macmillan.

Gupta, A. (2013). Play: Early childhood pedagogies and policies in a globalizing Asia. In O. F. Lillemyr, S. Dockett, \& B. Perry (Eds.), Varied perspectives of play and learning: Theory and research on early years' education. Charlotte: Information Age Publishing Inc.

Hallinger, P. (2003). Leading educational change: Reflections on the practice of instructional and transformational leadership. Cambridge Journal of Education, 33(3), 329-352.

Hallinger, P. (2011). Leadership for learning: Lessons from 40 years of empirical research. Journal of Educational Administration, 49(2), 125-142.

Harford, J. \& MacRuairc, G. (2008). Engaging student teachers in meaningful reflective practice. Teaching and Teacher Education, 24. Hopkins, CD \& Antes, RL. (1990). Educational Research: A structure for inquiry. 3rd Ed. Itasca, Illinois: FE Peacock.

Hargreaves, A. (2000). Four Ages of Professionalism and Professional Learning. Teachers and Teaching: History and Practice, 6(2), 151182. http://dx.doi.org/10.1080/713698714

Hargreaves, A. (2000). Four ages of professionalism and professional learning. Teachers and Teachng, History and Practice, 6(2), $151-182$

Hargreaves, A., \& Goodson, I. (1996). Teacher's professional lives: Aspirations and actualities. In I. Goodson \& A. Hargreaves (Eds.), Teachers' professional lives. London: Falmers Press.

Hargreaves, D. (1994) The new professionalism: the synthesis of professional and institutional development, Teaching and Teacher Education, 10(4), pp. $423 \pm 438$. 
Harvey, D. (1989) The Condition of Postmodernity (Cambridge, Polity Press).

Helsby, G. (1995) Teachers' construction of professionalism in England in the 1990s, Journal of Education for Teaching, 21(3), pp. 317 \pm 332. HELSBY, G. (2000) Changing Teachers' Work and Culture (Buckingham, Open University Press).

https://www.sec-ed.co.uk/best-practice/distributed-leadership-explained/

Jadoon, A.U.R. et. al., (2020).Challenges Faced by Newly Inducted Teachers Implementing Revised English Curriculum in Pakistan. English Language Teaching; Vol. 13, No. 7; Canadian Center of Science and Education. URL: https://doi.org/10.5539/elt.v13n7p52

Judyth Sachs (2015): Teacher professionalism: why are we still talking about it?, Teachers and Teaching, DOI: $10.1080 / 13540602.2015 .1082732$

Kongnyuy, P., (2015). Motivation and Changing Fortunes in Teachers' Output: Empirical Evidence from Selected Secondary Schools in North West Region of Cameroon. Journal of Education and Practice . Vol.6, No.5,www.iiste.org

Learners. Center for Applied Linguistics: Brock University, Ontario.

Leithwood, K. et.al. (2010).Testing a Conception of How School Leadership Influences Student Learning. Educational Administration Quarterly. 46: 671, DOI: 10.1177/0013161X10377347

Leithwood, K., \& Jantzi, D. (2005). A review of transformational school leadership research 1996-2005. Leadership and Policy in Schools, 4(3), 177-199.

Leithwood, K., Anderson, S. E., Mascall, B., \& Strauss, T. (2010a). School leaders ${ }^{\text {ee }}$ influences on student learning: The four paths. The Principles of Educational Leadership and Management, 13-30. 25.

Leithwood, K., Harris, A., \& Hopkins, D. (2008b). Seven strong claims about successful school leadership. School leadership and management, 28(1), 27-42. 26.

Linda Evans (2008) PROFESSIONALISM, PROFESSIONALITY AND THE DEVELOPMENT OF EDUCATION PROFESSIONALS, British Journal of Educational Studies, 56:1, 20-38, DOI: 10.1111/j.1467-8527.2007.00392.x

May Britt Postholm (2012) Teachers' professional development: a theoretical review, Educational Research, 54:4, 405-429, DOI: $10.1080 / 00131881.2012 .734725$

Mbua, F. N. (2003). Educational administration: Theory and practice. Limbe; Design House.

Ministry of Basic Education-MINEDUB (2018) nCameroon Nursery School Curriculum: English Subsystem

Mulford.B, (2003) School Leaders: Challenging Roles and Impact On Teacher And School Effectiveness. University of Tasmania. OECD Commissioned Paper

Mundry,S. (2005) Changing Perspectives In Professional Development; VOL. 14, NO. 1

National Policy Board for Educational Administration (2015). Professional Standards for Educational Leaders 2015. Reston, VA: Author.

National Policy Board for Educational Administration (NPBEA) (2015) Professional Standards for Educational Leaders proposed

Ndongko, T.M. (1989) A Handbook on Secondary School Administration. Ibadan: Heinemann Educational Books.

Nkafu Policy Institute. http://www.nkafu.foretiafoundation.org

Pilar Ruiz De Gauna , Capitolina Diaz , Valentin Gonzalez \& Isabel Garaizar (1995) Teachers' Professional Development as a Process of Critical Action Research, Educational Action Research, 3:2, 183-194, DOI: 10.1080/0965079950030205 
Pont.B, Nusche.D, \& Moorman.H, (2008) Improving School Leadership : Policy and Practice (Vol.1). www.oecd.org/publishing/corrigenda.

Rowland, C (2017) Principal Professional Development New Opportunities for a Renewed State Focus; The Education Policy Center at American Institutes for Research (AIR)

Spillane, J. P., Halverson, R., \& Diamond, J. B. (2001). Investigating school leadership practice: A distributed perspective. Educational researcher, 30(3), 23-28.

The National Center for Education Statistics (NCES.1997)Teacher Professionalization and Teacher Commitment: A Multilevel Analysis; U. S. Department of Education and Office of Educational Research and Improvement NCES 97-069

UNESCO (2016) Leading better learning: School leadership and quality in the Education 2030 agenda: UNESCO

University of Cape Coast \& University of Education, Winneba (2007) Management of Distance Education, University of Buea, Canmeroon

Vijayanthi Polgampala, A. S. Shen, H. Huang, F.(2017) STEM Teacher Education and Professional Development and Training: Challenges and Trends. Frontiers in Cognitive Psychology. Vol. 2, No. 2, pp. 61-65. doi: 10.11648/j.fcp.20170202.15

Wirba, A.V (2015) Leadership Style: School Perspective in Cameroon. Hindawi Publishing Corporation Education Research International Volume 2015, Article ID 439345, 9 pages http://dx.doi.org/10.1155/2015/439345 